\title{
Subclinical Pregnancy Toxemia-Induced Gene Expression Changes in Ovine Placenta and Uterus
}

\section{Ramanathan K. Kasimanickam*}

Department of Veterinary Clinical Sciences, College of Veterinary Medicine, Washington State University, Pullman, WA, USA

The objective was to elucidate gene expression differences in uterus, caruncle, and cotyledon of ewes with subclinical pregnancy toxemia (SCPT) and healthy ewes, and to identify associated biological functions and pathways involved in pregnancy toxemia. On Day 136 ( \pm 1 day) post-breeding, ewes $(n=18)$ had body condition score (BCS; $1-5 ; 1$, emaciated; 5 , obese) assessed, and blood samples were collected for plasma glucose and $\beta$-hydroxybutyrate (BHBA) analyses. The ewes were euthanized, and tissue samples

OPEN ACCESS

Edited by:

Fernando J. Peña Vega, University of Extremadura, Spain

Reviewed by:

Claudia Klein,

University of Calgary, Canada Carolina Maria Balao Da Silva, Polytechnic Institute of Portalegre,

Portugal

Jose-Ramiro Gonzalez-Montaña, University of León, Spain

*Correspondence:

Ramanathan K. Kasimanickam ramkasi@vetmed.wsu.edu

Specialty section:

This article was submitted to Animal Reproduction - Theriogenology, a section of the journal Frontiers in Veterinary Science

Received: 17 June 2016 Accepted: 17 August 2016 Published: 30 August 2016

Citation: Kasimanickam RK (2016) Subclinical Pregnancy Toxemia-Induced Gene Expression Changes in Ovine Placenta and Uterus. Front. Vet. Sci. 3:69. doi: 10.3389/fvets.2016.00069 were collected from the gravid uterus and placentomes. Based on BCS ( $2.0 \pm 0.02)$, glucose $(2.4 \pm 0.33)$, and BHBA $(0.97 \pm 0.06)$ concentrations, ewes $(n=10)$ were grouped as healthy $(n=5)$ and subclinical SCPT $(n=5)$ ewes. The mRNA expressions were determined by quantitative PCR method, and prediction of miRNA partners and target genes for the predicted miRNA were identified using miRDB (http://mirdb.org/ miRDB/). Top ranked target genes were used to identify associated biological functions and pathways in response to SPCT using PANTHER. The angiogenesis genes VEGF and PIGF, and AdipoQ, AdipoR2, PPARG, LEP, IGF1, IGF2, IL $1 b$, and TNF $\alpha$ mRNA expressions were lower in abundances, whereas hypoxia genes eNOS, HIF1a, and HIF $2 a$, and sFlt1 and KDR mRNA expressions were greater in abundances in uterus and placenta of SCPT ewes compared to healthy ewes $(P<0.05)$. The predicted miRNA and associated target genes contributed to several biological processes, including apoptosis, biological adhesion, biological regulation, cellular component biogenesis, cellular process, developmental process, immune system process, localization, metabolic process, multicellular organismal process, reproduction, and response to stimulus. The target genes were involved in several pathways including angiogenesis, cytoskeletal regulation, hypoxia response via HIF activation, interleukin signaling, ubiquitin proteasome, and VEGF signaling pathway. In conclusion, genes associated with blood vessel remodeling were lower in abundances and that the genes associated with hypoxic conditions were greater in abundances in the uteroplacental compartment of SCPT ewes. It is obvious that the factors that influence placental vascular development and angiogenesis as noted in this study set the course for hemodynamic changes and hence have a major impact on the rate of transplacental nutrient exchange, fetal growth, and health of the dam.

Keywords: sheep, pregnancy toxemia, uterus, placenta, gene expression 


\section{INTRODUCTION}

Pregnancy toxemia is a metabolic disorder of pregnant ewes, caused by an abnormal metabolism of carbohydrates and fats, which occurs during the final stage of pregnancy. The disease occurs more frequently in lean [body condition score (BCS) $<2$ in the 5-point scale] or obese (BCS $\geq 4$ ) animals, as well as in animals carrying two or more fetuses (1-4).

In ewes, glucose is the principal carbon source for placental and fetal oxidative metabolism and tissue formation $(5,6)$. A total of $30-50 \%$ of maternal glucose production in late gestation is taken up by uterine and fetal tissues (5-8), and $50-70 \%$ of this amount is used by the uteroplacental unit $(6,9,10)$. During late gestation, increased energy demands of the rapidly developing fetus(es) cause an unbalanced lipid and carbohydrate metabolism in the pregnant animal and putting them at risk to pregnancy toxemia $(1,2)$. During late pregnancy, the impaired fat and carbohydrate metabolism produces increased levels of fatty acids and ketone bodies, mainly $\beta$-hydroxybutyrate (BHBA), besides the decreased glucose concentration $(3,4)$.

Pregnancy requires an expansion of maternal blood volume, an increase of cardiac output, and a redistribution of blood to the uterus to meet the needs of the growing fetus. Normal maternal vascular adaptation during pregnancy includes enhanced vasodilation, with the greatest effect seen in the uterus. A range of pathophysiological factors including maternal stress due to poor nutrition, hyperthermia, or metabolic diseases such as pregnancy toxemia and eclampsia may affect important metabolic, transport, and hemodynamic functions of placentas. Excessive accumulation of free radicals affects placental development and function, and may subsequently impact both the fetus and dam (11-14).

Hypoxia plays critical roles in vascular development during embryonic and fetal growth in utero (15). In endothelial cells, hypoxic conditions drive the transcription of multiple genes, which control vascular function, expansion, and remodeling. Although tissue hypoxia is the main driving force for angiogenesis, a growing body of evidence has demonstrated that oxidative stress can also be a potent trigger for the development of new vessels. However, high level of acute oxidative stress and/or chronic oxidative stress has a vital role in development of vascular diseases (16), including placental ischemia. Development of insulin resistance diabetes and cardiovascular disease were associated with increased oxidative stress. Insulin resistance has been implicated as causative factor in the pathogenesis of ovine pregnancy toxemia (17).

The objective of this study was to determine the changes in gene expressions in uterus, caruncle, and cotyledon of ewes with subclinical pregnancy toxemia (SCPT).

\section{MATERIALS AND METHODS}

\section{Animals and Sample Collection}

Blood and tissue samples were collected during a previously reported clinical trial to determine the effect of daily tocopherol supplementation during late stage of pregnancy. Briefly, 18 pregnant ewes $(3.1 \pm 0.11$ years of age; Dorset cross; impregnated by two different sires by natural service) with similar breeding dates were selected and were maintained under normal pasture conditions. One week prior to the trial, the selected ewes were moved to the research facility. The ewes had access to $35 \mathrm{sq}$. ft/ewe paddock lots. In addition, they were fed free choice hay. The ewes were randomly assigned to receive (1) $500 \mathrm{mg}$ of $\alpha$-tocopherol $(n=6)$, (2) 1,000 mg of $\gamma$-tocopherol $(n=7)$, or (3) no treatment $(n=5)$ received a placebo. Animals were supplemented orally, once daily, from approximately 100 to $136( \pm 1)$ days post-breeding. On Day $136( \pm 1)$ post-breeding, all ewes received BCS (1-5; 1, emaciated; 5 , obese), and blood samples were collected by jugular venipuncture for plasma glucose and BHBA (in tubes anticoagulated with heparin $10 \mathrm{U} / \mathrm{mL}$ ) and serum 8 -isoprostane (in tubes without heparin) determination. All ewes were euthanized (Day $136 \pm 1)$, and tissue samples were collected immediately from the gravid uterus (full thickness) and placentomes (caruncle and cotyledon). Placentome and uterine samples were collected close to the umbilicus for consistency. Cotyledons were separated from caruncles by applying strong pressure. Tissue samples were placed in RNAlater (Qiagen Inc., Valencia, CA, USA) in 5-mL Nalgene ${ }^{\circledR}$ cryogenic vials (Sigma-Aldrich, St. Louis, MO, USA) and snap frozen immediately and stored at $-70^{\circ} \mathrm{C}$ for subsequent evaluation of mRNA expression. This study was approved by Virginia Tech Institutional Animal Care and Use Committee (IACUC; 04-068-CVM). Tissue Use Protocol was approved by IACUC at Washington State University (ASAF \#03922-001).

\section{Determination of Glucose, $\beta$-Hydroxybutyrate, and Isoprostane}

Blood samples (with heparin) were centrifuged at 3,500 $\times g$ for $15 \mathrm{~min}$, and plasma was separated and stored at $-20^{\circ} \mathrm{C}$ until analyzed. Determination of plasma glucose was done by the glucose oxidase enzymatic method (MyBioSource, LLC, San Diego, CA, USA) as described in the previous reports $(18,19)$, and the BHBA was measured enzymatically as described previously (20), in triplicates using 96-well plates. Plates were read using Glomax ${ }^{\circledR}$-Multi Detection System (Promega Corporation, Madison, WI, USA).

Blood samples (without heparin) were centrifuged at $1,200 \times g$ for $10 \mathrm{~min}$, and serum was separated and stored at $-20^{\circ} \mathrm{C}$ until analyzed. Isoprostane in serum samples were estimated by direct ELISA as described previously (21). Briefly, $100 \mu \mathrm{L}$ of anti-goat-8epi-PGF2 $\alpha$ antibody (MyBioSource, LLC, San Diego, CA, USA) was added in the 96-well plates that were pre-coated with standard or samples and kept at $4^{\circ} \mathrm{C}$ for at least $24 \mathrm{~h}$. After washing with buffer, $100 \mu \mathrm{L}$ of secondary antibody, raised in donkey anti-goat IgG-HRP (Santa Cruz Biotechnology, Inc.), was added to each well. After washing with buffer, $200 \mu \mathrm{L}$ of reagent containing the substrate of acetyl cholinesterase and then $50 \mu \mathrm{L}$ of stop solution were added. Plates were read at $450 \mathrm{~nm}$ using Glomax $^{\circledR}$-Multi Detection System (Promega Corporation, Madison, WI, USA), and serum concentrations of isoprostane were calculated from standard curves.

\section{Real-Time Polymerase Chain Reaction Total RNA Extraction from Tissues}

Total RNA was extracted from uterus, caruncle, and cotyledon tissues with RNeasy Mini Kit (QIAGEN Inc., Valencia, CA, USA) 
according to the manufacturer's protocol. RNA concentration was measured using a NanoDrop spectrophotometer (Thermo Fisher Scientific Inc., West Palm Beach, FL, USA). Sample absorbance ratio of 260/280 wavelength was observed to ensure the purity of RNA and they were 1.96-2.00. DNase treatment was performed using deoxyribonuclease 1 (amplification grade, Invitrogen ${ }^{\mathrm{TM}}$, Carlsbad, CA, USA). Briefly, the $1 \mu \mathrm{g}$ of RNA sample was added with $1 \mu \mathrm{l}$ of $10 \times$ DNase I reaction buffer, $1 \mu$ l of 10 DNase I enzyme, and DEPC-treated water. The mix was incubated for $15 \mathrm{~min}$ at room temperature. After the reaction, the enzyme was inactivated by adding $1 \mu \mathrm{l}$ of $25 \mathrm{mM}$ EDTA and heating to $65^{\circ} \mathrm{C}$ for $10 \mathrm{~min}$. Then, the RNA samples were stored at $-20^{\circ} \mathrm{C}$ until complementary DNA (cDNA) preparation.

\section{Polymerase Chain Reaction of Selected Genes of Interest}

The mRNA was reverse transcribed to cDNA. The cDNA samples were prepared using the iScript cDNA Synthesis kit (Bio-Rad Laboratories, Hercules, CA, USA). A 500- $\eta$ sample of RNA was reverse transcribed in $20-\mu \mathrm{L}$ reaction at the incubating conditions of $25^{\circ} \mathrm{C}$ for $5 \mathrm{~min}, 42^{\circ} \mathrm{C}$ for $30 \mathrm{~min}$, and $85^{\circ} \mathrm{C}$ for $5 \mathrm{~min}$; $25 \eta \mathrm{g} / \mu \mathrm{L}$ RNA equivalent cDNA was obtained. Qiagen Tag PCR master mix (Qiagen, Valencia, CA, USA), a pre-mixed solution, was used to amplify the fragment of the genes of interest. Final concentration of the primers was $0.3 \mu \mathrm{M}$. Initial denaturation was set at $94^{\circ} \mathrm{C}$ for $3 \mathrm{~min}$. Followed by 30 cycles of denaturation at $94^{\circ} \mathrm{C}$ for $1 \mathrm{~min}$, annealing at $55^{\circ} \mathrm{C}$ for $1 \mathrm{~min}$ and extension at $72^{\circ} \mathrm{C}$ were programed. A final extension step at $72^{\circ} \mathrm{C}$ for $10 \mathrm{~min}$ was included in thermocycling conditions. Primers (Table S1 in Supplementary Material) were designed either using the NCBI website or primer express version 3.0 (Applied Biosystems Inc., Carlsbad, CA, USA). Consideration was given to the set of primers (forward and reverse primers) to ensure separation of at least an intron and melting temperatures, and CG content were set at optimal, or close to optimal level. Amplicon was run on a $2 \%$ agarose gel and stained with ethidium bromide for visualization to ensure a single amplicon for a set of primers.

\section{Determination of mRNA Expression Using Real-Time PCR}

SYBR green chemistry was applied to observe relative mRNA expression. Fast SYBR green master mix $(2 \times)$ (Applied Biosystems Inc., Carlsbad, CA, USA) was used to prepare the reaction mix. The final concentration of each primer was $0.3 \mu \mathrm{M}$. A $20-\mu \mathrm{L}$ aliquot of three technical replicates was used for each sample. A 1.6- $\mu \mathrm{L}$ volume of $25 \mathrm{ng} / \mu \mathrm{L}$ RNA equivalent cDNA was present in the total volume of the three triplicates. StepOne Plus instrument (Applied Biosystems Inc., Carlsbad, CA, USA) was used for the real-time PCR runs. Precycling stage was maintained at $95^{\circ} \mathrm{C}$ for $20 \mathrm{~s}$. Forty cycles of amplification was carried out with the conditions of $95^{\circ} \mathrm{C}$ for $3 \mathrm{~s}$ and $60^{\circ} \mathrm{C}$ for $30 \mathrm{~s}$ (fast ramp speed conditions for the fast mixture). A continuous dissociation step was added to look for additional amplification products.

Carboxy-X-rhodamine (ROX) dye was set up for the passive internal reference. The baseline was automatically adjusted to obtain threshold cycles of each sample. Threshold cycles were normalized to an endogenous control, $\beta$-actin. A standard curve was obtained using one in five dilutions for each set of primer in order to check the amplification efficiency. Correlation coefficient for the dilution curve was $\geq 0.9900$.

\section{Morphometry Analysis of Placental Unit}

The placentome samples collected for histological evaluation were fixed in $10 \%$ neutral buffered formalin, sectioned at $5 \mu \mathrm{m}$, and stained with hematoxylin and eosin. They were evaluated on a Nikon E400 Eclipse microscope, and photomicrographs (100×) were taken with a Nikon camera with a 3 chip. Images were processed with Nikon Act 1 software. Image processing and morphometry analysis were performed using ImageJ $1.42 \mathrm{q}$ (NIH, USA) to evaluate the fractal dimension and lacunarity as described previously (22). A fractal dimension is a scaling rule comparing how a pattern's detail changes with the scale at which it is considered. The fractal dimension is a valuable parameter to describe the complexity. Lacunarity is a measure of homogeneity of structure or the degree of structural variance within an object. Briefly, FarcLac 2.5 (NIH, USA) was used to perform fractal dimension. The FracLac scan images using a shifting grid algorithm that can do multiple scans from different locations on each image. The average value over all locations was considered as the final estimate of fractal dimension. During the same analytical process, lacunarity was also calculated. It was estimated as the average of the coefficient of variation for pixel density over all grid sizes and locations. A total of 30 locations were evaluated for each sample.

\section{Prediction of Functional Gene and miRNA Partners, and Its Biological Function and Pathways}

Predictions of functional gene network and their miRNA partners were determined using GeneMANIA prediction server, as described previously (23-26). Target genes were predicted using miRDB (http://mirdb.org/miRDB/) for the predicted miRNAs, and top ranked predicted genes were run using PANTHER classification system (27) to identify associated biological processes and pathways in response to pregnancy toxemia.

\section{Animal Grouping and Data Management}

Based on BCS, glucose, and BHBA concentrations (Table 1), ewes $(n=10)$ were grouped as healthy $(n=5)$ and SCPT $(n=5)$ ewes (4). In the previous studies $(21,22,28)$, tocopherol treatment was considered as the main effect. The alpha and gamma tocopherol concentrations in placenta, uterus, and serum on Day 136 between healthy and SCPT ewes were not found to be different (Table S2 in Supplementary Material). Thus, tocopherol treatment categories were excluded in the overall analysis of this study. Ewes' serum isoprostane concentrations, mRNA relative fold changes and values of fractal dimension, and lacunarity of placental unit were grouped for the healthy and the SCPT categories for analysis. Three ewes in SCPT group had twins.

\section{Statistical Analysis}

The data were analyzed using SAS software (SAS version 9.12, SAS Institute Inc., Cary, NC, USA). Mean \pm SEM differences in BCSs and plasma glucose and BHBA concentrations between healthy 
TABLE 1 | Mean \pm SEM body condition scores (BCSs) and plasma glucose, and $\beta$-hydroxybutyrate $(B H B A)$ concentrations in healthy ewes $(n=5)$ and ewes with subclinical pregnancy toxemia $(n=5)$.

\begin{tabular}{|c|c|c|c|c|c|}
\hline \multicolumn{2}{|c|}{ BCS } & \multicolumn{2}{|c|}{ Glucose (mmol/L) } & \multicolumn{2}{|c|}{ BHBA (mmol/L) } \\
\hline Healthy ewes & SCPT ewes & Healthy ewes & SCPT ewes & Healthy ewes & SCPT ewes \\
\hline $2.6 \pm 0.05^{a}$ & $2.0 \pm 0.02^{b}$ & $3.2 \pm 0.10^{\mathrm{a}}$ & $2.4 \pm 0.33^{b}$ & $0.34 \pm 0.05^{a}$ & $0.97 \pm 0.06^{b}$ \\
\hline
\end{tabular}

SCPT, subclinical pregnancy toxemia.

and SCPT ewes were calculated using ANOVA. Mean \pm SEM differences in alpha tocopherol and gamma tocopherol concentrations in placenta, uterus, and serum of healthy SCPT ewes were calculated using ANOVA. The differences in fractal dimension and lacunarity in uteroplacental unit between healthy and SCPT ewes were tested by ANOVA. The PCR data were subjected to ANOVA using $2^{-\Delta \Delta C t}$ values to ascertain statistical significance of any differences in genes expressions between healthy and SCPT ewes (29).

\section{RESULTS}

\section{Plasma Glucose and $\beta$-Hydroxybutyrate, and Serum Isoprostane Concentrations}

Mean \pm SEM BCS and plasma glucose, and BHBA concentrations for healthy ewes $(n=5)$ and for ewes with SPCT $(n=5)$ are presented in Table 1. The BCS and concentrations of glucose were lower and BHBA was greater in SCPT ewes compared to healthy ewes $(P<0.05)$. The serum isoprostane concentrations were different between healthy and SCPT ewes, $244.6 \pm 14.2$ and $292.9 \pm 9.1$, respectively $(P<0.05)$.

\section{mRNA Expression between Healthy and Subclinical Pregnancy Toxemia Ewes}

The VEGF, PlGF, AdipoQ, AdipoR2, PPARG, Lep, IGF1, IGF2, $I L 1 b$, and $T N F \alpha$ mRNA expressions were lower in abundance in cotyledon, caruncle, and uterus of SCPT ewes compared to healthy ewes (Figure 1; $P<0.05$ ). The sFlt1, KDR, eNOS, HIF1a, and HIF $2 a$ mRNA expressions were greater in abundance in cotyledon, caruncle, and uterus of SCPT ewes compared to healthy ewes $(P<0.05)$. The HIF2 $b$ mRNA expression was not different between healthy and SCPT ewes $(P>0.05)$ in cotyledon, caruncle, and uterus. The $I L-8$ mRNA expression was lower in abundance in cotyledon and in uterus $(P<0.05)$ but not in caruncle $(P>0.1)$ of SCPT ewes compared to healthy ewes. The AdipoR1 mRNA expression was lower in abundance in both units of the placenta $(P<0.05)$ but not in the uterus $(P>0.1)$ of SCPT ewes compared to healthy ewes. The IL6 mRNA expression was lower in abundance in the uterus of SCPT ewes compared to healthy ewes $(P<0.05)$ and the expression was not different in both units of placenta of SCPT and healthy ewes $(P>0.1)$.

\section{Morphometry Analysis of Placental Unit}

The healthy ewes had increased fractal dimension and decreased lacunarity in their placental vascular network compared to SCPT ewes (Figure 2; $P<0.05$ ).

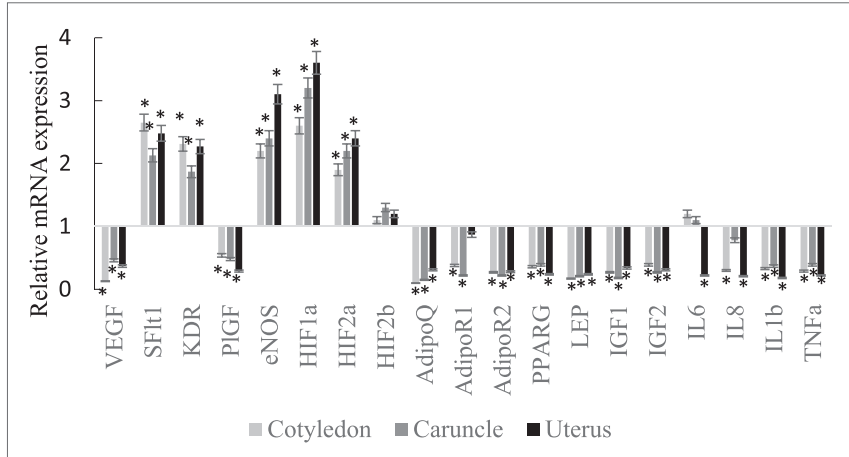

FIGURE 1 | mRNA expression ( \pm SEM) of vascular endothelial growth factor (VEGF), kinase insert domain receptor (KDR), soluble Fms-like tyrosine kniase-1 (sFlt1), endothelial nitric oxide synthase (eNOS), and placental growth factor (PIGF), hypoxia-inducible factors (HIF-1a, HIF$2 a$, and $H I F-2 b)$, adiponectin (AdipoQ), adiponectin receptor (AdipoR)1, AdipoR2, peroxisome proliferator-activated receptor gamma (PPAR $\gamma$ ), insulin-like growth factor (IGF)1, IGF2, and leptin (LEP), interleukin (IL)-6, IL-8, IL-1b, and tumor necrosis factor alpha (TNF $\boldsymbol{\alpha}$ ). (Gene expression of the control was set at 1, and gene expression of SGPT was related to the control; $\left.{ }^{*} P<0.05\right)$.

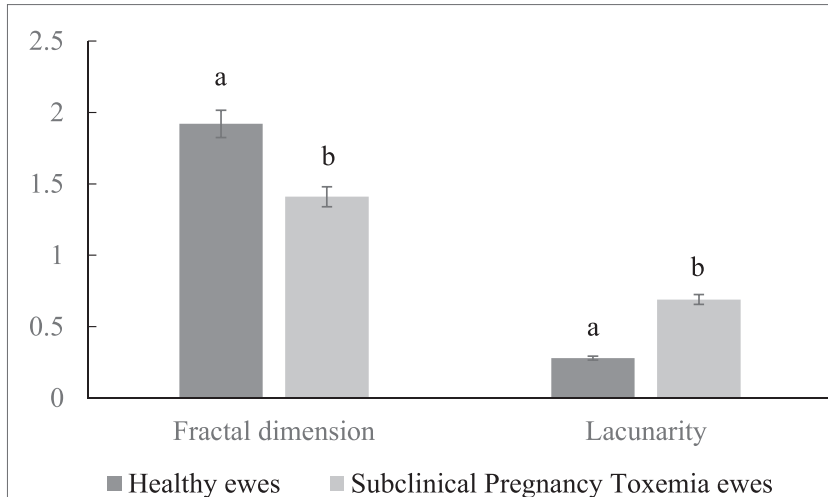

FIGURE 2 | Mean \pm SEM fractal dimension and lacunarity of placental vascular network of healthy and subclinical pregnancy toxemic ewes. Bars with different letters indicates parameters were significantly $(P<0.05)$ different between healthy and SCPT ewes.

\section{Predicted Functional Gene and miRNA Partners}

Predicted functional genes investigated in this study are interrelated (Figure 3). Different line colors represent the types of evidence for the association. Predicted association was made based on neighborhood, gene fusion, co-occurrence, coexpression, 

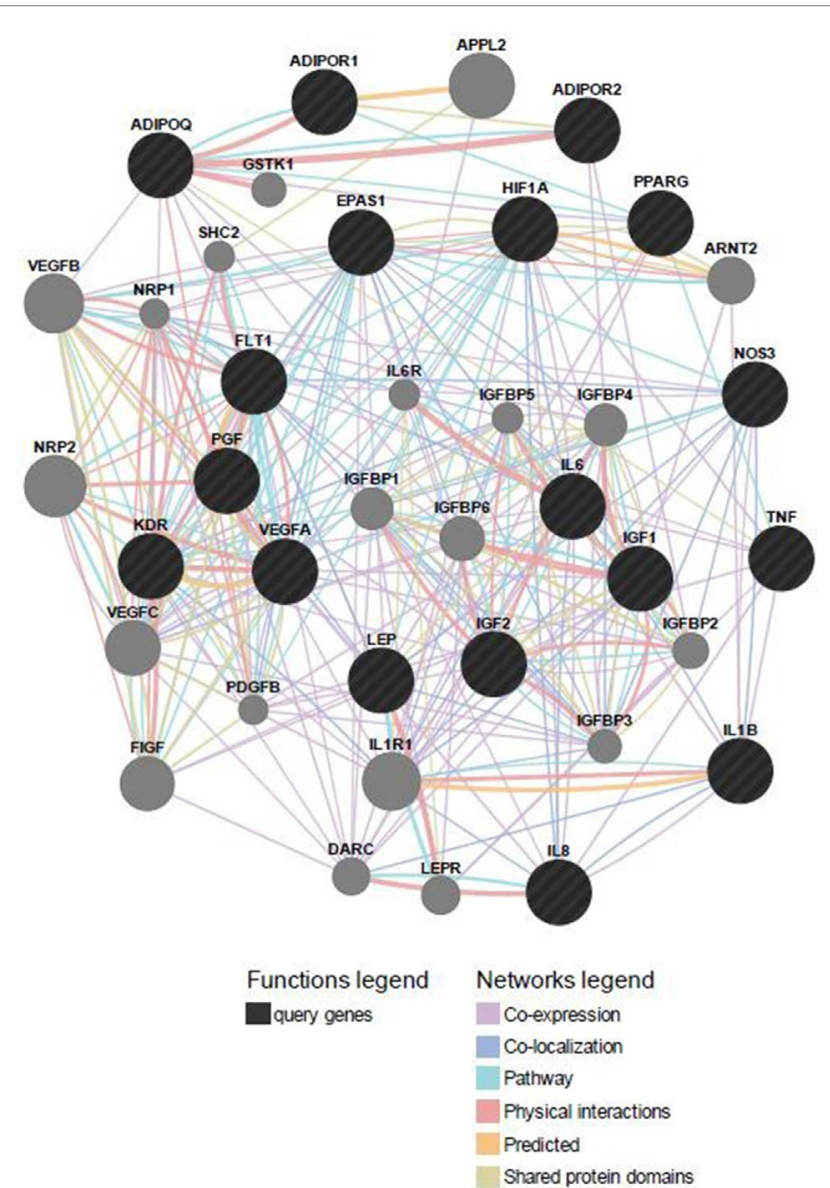

FIGURE 3 | Predicted functional gene partners: investigated genes were used as input genes; additional functional partners were obtained; and genes were connected by various links based on different functions.

experiments, databases, text mining, homology, and at a confidence score of 0.90 . The relationship network of functional genes and miRNA is presented in Figure 4.

PANTHER analysis revealed that the predicted miRNA and associated target genes contributed to several biological processes, including apoptosis, biological adhesion, biological regulation, cellular component organization or biogenesis, cellular process, developmental process, immune system process, localization, metabolic process, multicellular organismal process, reproduction, and response to stimulus (Figure 5). The target genes were involved in several pathways including angiogenesis, cytoskeletal regulation, hypoxia response via HIF activation, interleukin signaling, ubiquitin proteasome, and VEGF signaling pathway (Figure 6).

\section{DISCUSSION}

The goal of this study was to elucidate the differences in gene expressions of the uteroplacental compartment and morphometry of placental vascular network between healthy and SCPT ewes.
We used BCS and biochemical parameters to distinguish SCPT ewes from healthy ewes. The SCPT ewes had lowered BCS and blood glucose concentration and increased BHBA concentration without any clinical signs of the disease (4). The findings of the study indicated that expressions of the genes (VEGF and PlGF) associated to vascular remodeling were lower in abundances in SGPT ewes; the genes (HIF1a, HIF2a, and eNOS) associated to hypoxic condition were greater in abundances in SGPT ewes; morphometry analysis of angiogenic parameters of uteroplacental unit displayed reduced vascularization suggestive of hypoxic conditions in SCPT ewes compared to healthy ewes.

In this study, the BCS and concentrations of glucose were lower and BHBA was greater in SCPT ewes compared to healthy ewes. Susceptible, thin ewes develop ketosis because a chronically inadequate ration is offered or because other diseases such as lameness or dental diseases limit intake and, with increasingly insufficient energy to meet increasing fetal demands, the ewe or doe mobilizes more body fat, with resultant ketone body production and hepatic lipidosis. The ewes included in the study were observed to have normal appetite. Ewes with a poor BCS or that are overconditioned and carrying more than one fetus are most at risk of developing pregnancy toxemia, although the condition can occur even in ideally conditioned ewes on an adequate ration. In this study, three animals had twins and no differences between ewes carrying singletons and twins were detected.

A multifaceted variety of angiogenic growth factors are recognized as regulators of the vascularization process, and these include VEGF, PlGF, sFlt-1, KDR, and HIFs (30-32). The sheep placenta produces these angiogenic factors throughout gestation and tissue- and cell-specific patterns of expression have been documented in normal pregnancies (33) and in those where placental insufficiency and fetal growth restriction have been induced by maternal hyperthermia (34). In the current study, VEGF and PlGF gene expressions were lower in abundances, whereas sFlt1 and KDR expression were greater in abundances in placenta and uterus of SCPT ewes compared to healthy ewes. In addition, HIF1a, HIF2a, and eNOS expressions were greater in abundance in placenta and uterus of SCPT ewes. In women, sFlt- 1 is increased, and VEGF and PlGF are decreased in placenta under hypoxic conditions (35-40). It is possible that the binding of sFlt1 to free VEGF and PlGF reduces their availability, thereby causing endothelial cell dysfunction, leading to ischemia, proteinuria, and other maternal systemic symptoms in SCPT ewes $(41,42)$.

Hypoxia-inducible factor is the main regulator of the cellular response to low oxygen levels in mammalian species. The HIF1a and HIF2 $a$ both play important roles in vascular development and endothelial function (43-45). The HIF1a is the molecular link between hypoxia and pregnancy disorders as it induces antiangiogenic factor sFlt1 and vasoconstrictor Urotensin-II (46, 47). The HIF2a reported to have effects on cell proliferation, invasion, and angiogenesis, processes important in placentation (48). So, in human, it is apparent that balanced expressions of HIFs are needed for normal vascularization, whereas excessive HIF results in endothelial dysfunction. In the present study, increased expressions of HIF1a and HIF $2 a$ in the placenta and the uterus of SCPT ewes plausibly induced excessive hypoxia and caused 


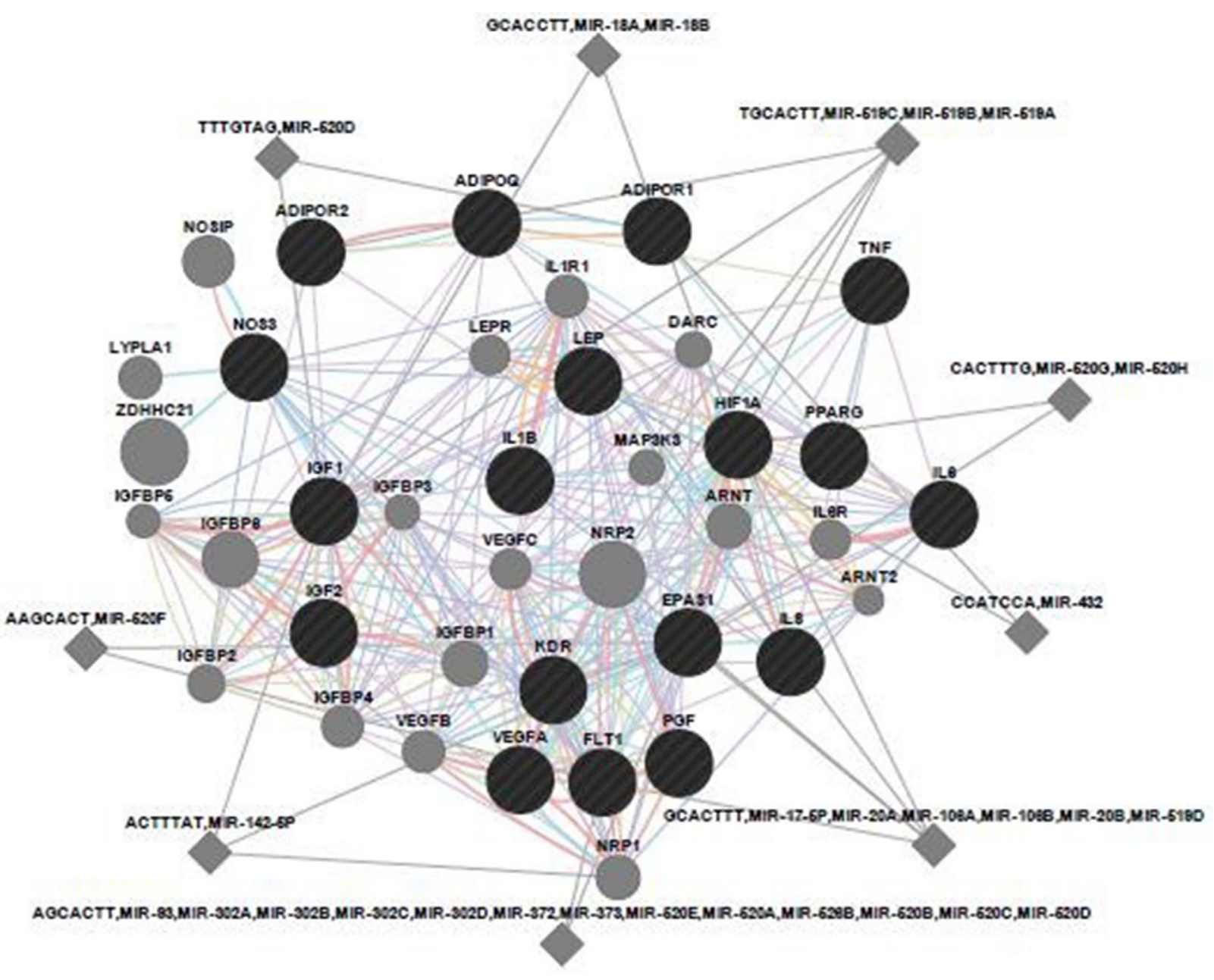

\title{
Functions legend query genes
}

\author{
Networks legend \\ co-expression \\ Co-localization \\ Genetic interactions \\ Pathway \\ Physical interactions \\ Predicted \\ Shared protein domains \\ mRNA-target-predictions-2013
}

FIGURE 4 | Predicted functional gene and their miRNA partners.

poor placental vascularization by suppressing VEGF and PlGF via increased $s F l t 1$ and $K D R$.

It is evident that PPAR $\gamma$ plays a predominant role in normal vascular function $(49,50)$ and in the differentiation of labyrinthine trophoblast lineages (51) which, along with the fetal endothelium, form the vascular exchange interface with maternal blood (52). The PPAR $\gamma$ null placentas develop a malformed labyrinth zone (52), suggesting a critical role for PPAR $\gamma$ in the progression of normal pregnancy. Moreover, administration of a PPAR $\gamma$ agonist improved several signs of this condition. Conversely, PPAR antagonist treatment to pregnant rats resulted in significant decrease in VEGF and significant increase in sFlt-1. In this study, $P P A R \gamma$ mRNA abundances were lower in SCPT ewes compared to healthy ewes. This may have caused ischemia, endothelial dysfunction, proteinuria, and an imbalance of angiogenic proteins in SCPT ewes $(41,42,53)$. 


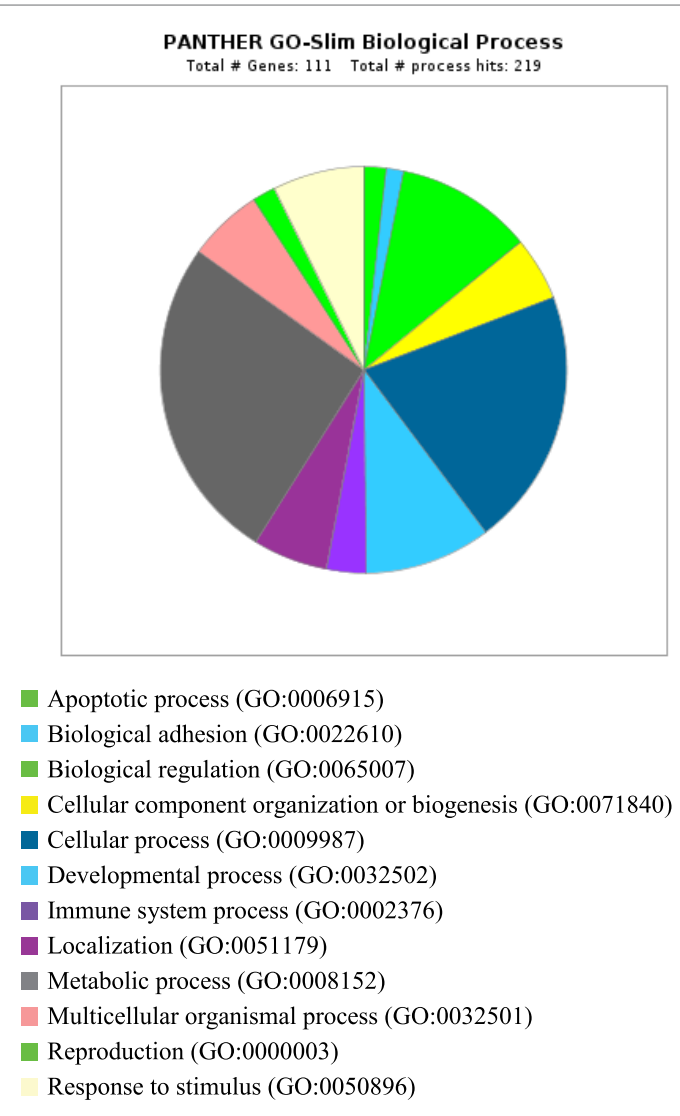

FIGURE 5 | Biological process for integrated genes and miRNAs in pregnancy toxemia in ewes. GO biological process; total number of genes: 111; total number of process hit: 219.

Pregnancy toxemia is characterized by a clustering of biochemical and clinical characteristics, including insulin resistance (17). Similar to other pregnancy complications, alterations in the levels of insulin, IGF1, leptin and adiponectin, cytokines, and VEGF also occur in this condition. Further, these metabolic syndromes are associated with a low-grade, chronic state of inflammation characterized by increased circulating free fatty acids, and chemoattraction of macrophages, which also produce inflammatory mediators into the local milieu (54-56). These effects are further amplified by the release of inflammatory cytokines, such as IL1 $\beta, I L 6$, and TNF $\alpha$. It should be noted that adiponectin was implicated in the pathogenesis of insulin resistance. Administration of adiponectin significantly ameliorates insulin resistance. Further adiponectin enhances fatty acid oxidation and glucose uptake by decreasing circulating free fatty acids and improving whole-body insulin action (57). In this study, SCPT ewes had lower adiponectin expression in placenta and uterus plausibly lowered the glucose utilization by the uteroplacental unit contributed to hypoxic conditions. It should be noted that there is a functional network involving VEGF, $I G F$, and $M M P$ in placenta and uterus, which is important for normal placentation (58). The IGF2 signaling has been found to upregulate VEGF function. IGF2 has effects on cell proliferation

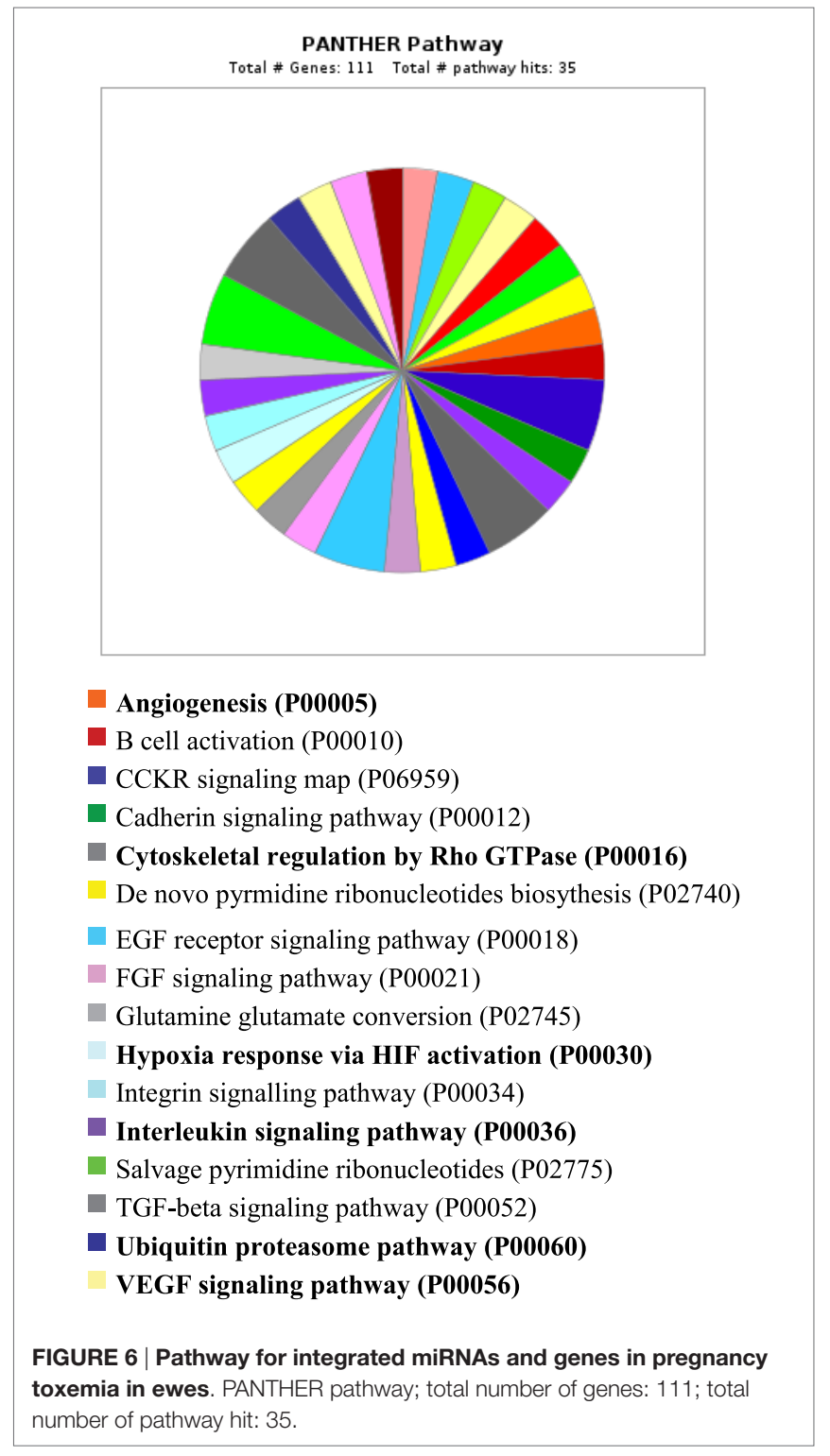

and apoptosis; lower levels of IGF2 may conceivably reduce cell proliferation and placental mass, in addition to increasing apoptosis (59).

In this study, circulating isoprostane was increased in SCPT ewes compared to healthy ewes. Increased isoprostane concentrations are reported in normal and IUGR pregnancies (60, 61). It should be noted that mild oxidative stress and resultant increase in isoprostane might be involved in normal pregnancy. However, in placental abnormalities caused by oxidative stress, there is increased isoprostane generation (62) as noted in this study.

Remarkably, the genes investigated and predicted miRNAs and targeted genes were related to several biological functions. The targeted genes contributed to several biological processes, such as apoptotic process, biological adhesion, biological regulation, cellular component organization or biogenesis, cellular process, developmental process, immune system process, 
localization, metabolic process, multicellular organismal process, reproduction, and response to stimulus. The target genes were involved in several pathways including angiogenesis, cytoskeletal regulation, hypoxia response via HIF activation, interleukin signaling, ubiquitin proteasome, and VEGF signaling pathway. The biological functions explained the association of pregnancy toxemia (regulation of metabolic process: carbohydrate and glucose metabolism and catabolic process), placental vascularization (regulation of angiogenesis: blood vessel development, exocytosis and apoptosis and involvement of interleukins, endothelial growth factors, insulin-like growth factors, and adipokines), and hypoxic condition (regulation of nitric oxide synthase and hypoxia).

\section{CONCLUSION}

Pregnancy is a dominant physiological state during which an alteration in metabolism may be expected because of a greater demand for nutrients by developing fetus. In addition to alterations in nutrient partitioning, the placentogenesis are tightly associated with diverse pathophysiological changes in the feto-maternal compartment. The findings of the study indicated that expressions of the genes associated with vascular remodeling were lower in abundances and that the genes associated with hypoxic condition were greater in abundances in the uteroplacental compartment in SCPT ewes. In addition, morphometry analysis of angiogenic parameters of uteroplacental

\section{REFERENCES}

1. Andrews A. Pregnancy toxaemia in the ewe. In Pract (1997) 19:306-12. doi:10.1136/inpract.19.6.306

2. Andrews AH. Effects of glucose and propylene glycol on pregnancy toxaemia in ewes. Vet $\operatorname{Rec}(1982)$ 110:84-5. doi:10.1136/vr.110.4.84

3. Wastney ME, Wolff JE, Bickerstaffe R. Glucose turnover and hepatocyte glucose production of starved and toxaemic pregnant sheep. Aust J Biol Sci (1983) 36:271-84. doi:10.1071/BI9830271

4. Lacetera N, Bernabucci U, Ronchi B, Nardone A. Effects of subclinical pregnancy toxemia on immune responses in sheep. Am J Vet Res (2001) 62:1022-4. doi:10.2460/ajvr.2001.62.1020

5. Bell AW. Pregnancy and fetal metabolism. In: Forbes JM, France JM, editors. Quantitative Aspects of Ruminant Digestion and Metabolism. Oxford, UK: CAB International (1993). p. 406-31.

6. Hay WW. Regulation of placental metabolism by glucose supply. Reprod Fertil Dev (1995) 7:365-75. doi:10.1071/RD9950365

7. Hay WW, Molina RA, DiGiacomo JE, Meschia G. Model of placental glucose consumption and glucose transfer. Am J Physiol (1990) 258:R569-77.

8. Hay WJ, Lin CC, Meznarich HK. Effect of high levels of insulin on glucose utilization and glucose production in pregnant and nonpregnant sheep. Proc Soc Exp Biol Med (1988) 189:275-84. doi:10.3181/00379727-189-42807

9. Molina R, Meschia G, Battagli FC, Hay WW. Gestational maturation of placental glucose transfer capacity in sheep. Am J Physiol (1991) 261:R697-704.

10. Owens JA, Falconer J, Robinson JS. Effect of restriction of placental growth on oxygen delivery to and consumption by the pregnant uterus and fetus. J Dev Physiol (1987) 9:137-50.

11. Burton GJ, Hempstock J, Jauniaux E. Oxygen, early embryonic metabolism and radical mediated embryopathies. Reprod Biomed Online (2003) 6:84-96. doi:10.1016/S1472-6483(10)62060-3

12. Wiznitzer A, Furman B, Mazor M, Reece EA. The role of prostanoids in the development of diabetic embryopathy. Semin Reprod Endocrinol (1999) 17:175-81. doi:10.1055/s-2007-1016224 unit displayed reduced vascularization suggestive of hypoxic conditions in SCPT ewes compared to healthy ewes. It is obvious that the factors that influence placental vascular development and angiogenesis as noted in this study set the course for hemodynamic changes and hence have a major impact on the rate of transplacental nutrient exchange, fetal growth, and health of the dam.

\section{AUTHOR CONTRIBUTIONS}

Acquisition of funding; conception, design, and collection of data; morphometry analysis; data analysis and interpretation; and drafting of the manuscript, tables, and figures. The author confirms being the sole contributor of this work and approved it for publication.

\section{FUNDING}

This study was funded by College of Veterinary Medicine, Washington State University, Pullman WA 99164, USA, and by Virginia-Maryland Regional College of Veterinary Medicine, Blacksburg, VA 24061, USA.

\section{SUPPLEMENTARY MATERIAL}

The Supplementary Material for this article can be found online at http://journal.frontiersin.org/article/10.3389/fvets.2016.00069
13. Jauniaux E, Hempstock J, Greenwold N, Burton GJ. Trophoblastic oxidative stress in relation to temporal and regional differences in maternal placental blood flow in normal and abnormal early pregnancy. Am J Pathol (2003) 162:115-25. doi:10.1016/S0002-9440(10)63803-5

14. Jauniaux E, Watson AL, Hempstock J, Bao Y-P, Skepper JN, Burton GJ. Onset of placental blood flow and trophoblastic oxidative stress: a possible factor in human early pregnancy failure. Am J Pathol (2000) 157:2111-22. doi:10.1016/ S0002-9440(10)64849-3

15. Sherer DM, Abulafia O. Angiogenesis during implantation, and placental and early embryonic development. Placenta (2001) 22:1-13. doi:10.1053/ plac. 2000.0588

16. Zafari AM, Ushio-Fukai M, Akers M, Yin Q, Shah A, Harrison DG, et al. Role of NADH/NADPH oxidase derived $\mathrm{H}_{2} \mathrm{O}_{2}$ inangiotensin II-induced vascular hypertrophy. Hypertension (1998) 32:488-95. doi:10.1161/01.HYP.32.3.488

17. Duehlmeier R, Fluegge I, Schwert B, Ganter M. Insulin sensitivity during late gestation in ewes affected by pregnancy toxemia and in ewes with high and low susceptibility to this disorder. J Vet Intern Med (2013) 27(2):359-66. doi:10.1111/jvim.12035

18. Szymanski LA, Schneider JE, Satragno A, Dunshea FR, Clarke IJ. Mesenteric infusion of a volatile fatty acid prevents bodyweight loss and transiently restores luteinizing hormone pulse frequency in ovariectomised, food-restricted ewes. J Neuroendocrinol (2011) 23:699-710. doi:10.1111/j.1365-2826.2011.02173.x

19. Udum CD, Cetin M, Balci F, Gunes N, Hecer C. Effects of plasma insulin, glucose and NEFA concentrations of feeding frequency during long term in lambs. J Biol Environ Sci (2008) 2:45-51.

20. Keller-Wood M, Feng X, Wood CE, Richards E, Anthony RV, Dahl GE, et al. Elevated maternal cortisol leads to relative maternal hyperglycemia and increased stillbirth in ovine pregnancy. Am J Physiol Regul Integr Comp Physiol (2014) 307:R405-13. doi:10.1152/ajpregu.00530.2013

21. Kasimanicam RK, Kasimanickam VR. Effect of tocopherol supplementation on serum 8-epi-prostaglandin F2 alpha and adiponectin concentrations, and mRNA expression of PPAR $\gamma$ and related genes in ovine placenta and uterus. Theriogenology (2011) 76:482-91. doi:10.1016/j.theriogenology.2011.02.025 
22. Kasimanickam RK, Kasimanickam VR, Rodriguez JS, Pelzer KD, Sponenberg PD, Thatcher CD. Tocopherol induced angiogenesis in placental vascular network in late pregnant ewes. Reprod Biol Endocrinol (2010) 8:86. doi:10.1186/1477-7827-8-86

23. Jensen LJ, Kuhn M, Stark M, Chaffron S, Creevey C, Muller J, et al. STRING 8 - a global view on proteins and their functional interactions in 630 organisms. Nucleic Acids Res (2009) 37:D412-6. doi:10.1093/nar/gkn760

24. Kasimanickam VR, Kasimanickam RK, Rogers HA. Immunolocalization of retinoic acid receptor-alpha, -beta, and -gamma, in bovine and canine sperm. Theriogenology (2013) 79:1010-8. doi:10.1016/j.theriogenology.2013.01.011

25. Warde-Farley D, Donaldson SL, Comes O, Zuberi K, Badrawi R, Chao P, et al. The GeneMANIA prediction server: biological network integration for gene prioritization and predicting gene function. Nucleic Acids Res (2010) 38:W214-20. doi:10.1093/nar/gkq537

26. Kasimanickam VR, Kasimanickam RK, Dernell WS. Dysregulated microRNA clusters in response to retinoic acid and CYP26B1 inhibitor induced testicular function in dogs. PLoS One (2014) 9:e99433. doi:10.1371/journal. pone. 0099433

27. Thomas PD, Kejariwal A, Campbell MJ, Mi H, Diemer K, Guo N, et al. PANTHER: a browsable database of gene products organized by biological function, using curated protein family and subfamily classification. Nucleic Acids Res (2003) 31:334-41. doi:10.1093/nar/gkg115

28. Kasimanickam RK, Kasimanickam VR, Haldorson GJ, Tibary A. Effect of tocopherol supplementation during last trimester of pregnancy on mRNA abundances of interleukins and angiogenesis in ovine placenta and uterus. Reprod Biol Endocrinol (2010) 12(8):86. doi:10.1186/1477-7827-8-86

29. Livak KJ, Schmittgen TD. Analysis of relative gene expression data using realtime quantitative PCR and the 2(-delta delta C(T)) method. Methods (2001) 25:402-8. doi:10.1006/meth.2001.1262

30. Frusca T, Morassi L, Pecorelli S, Grigolato P, Gastaldi A. Histological features of uteroplacental vessels in normal and hypertensive pregnancies in relation to birthweight. Br J Obstet Gynaecol (1989) 96:835-9. doi:10.111 1/j.1471-0528.1989.tb03324.x

31. Gerhardt H, Golding M, Fruttiger M, Ruhrberg C, Lundkvist A, Abramsson A, et al. VEGF guides angiogenic sprouting utilizing endothelial tip cell filopodia. J Cell Biol (2003) 161:1163-77. doi:10.1083/jcb.200302047

32. De Falcol $\mathrm{S}$. The discovery of placenta growth factor and its biological activity. Exp Mol Med (2012) 44:1-9. doi:10.3858/emm.2012.44.1.025

33. Borowicz PP, Arnold DR, Johnson ML, Grazul-Bilska AT, Redmer DA, Reynolds LP. Placental growth throughout the last two thirds of pregnancy in sheep: vascular development and angiogenic factor expression. Biol Reprod (2007) 76:259-67. doi:10.1095/biolreprod.106.054684

34. Reynolds LP, Redmer DA. Angiogenesis in the placenta. Biol Reprod (2001) 64:1033-40. doi:10.1095/biolreprod64.4.1033

35. Regnault TRH, Galan HL, Parker TA, Anthony RV. Placental development in normal and compromised pregnancies - a review. Placenta (2002) 23(Suppl A, 16):S119-29. doi:10.1053/plac.2002.0792

36. Levine RJ, Maynard SE, Qian C, Lim KH, England LJ, Yu KF, et al. Circulating angiogenic factors and the risk of preeclampsia. N Engl J Med (2004) 350:672-83. doi:10.1056/NEJMoa031884

37. Gu Y, Lewis DF, Wang Y. Placental productions and expressions of soluble endoglin, soluble fms-like tyrosine kinase receptor-1, and placental growth factor in normal and preeclamptic pregnancies. JClin Endocrinol Metab (2008) 93:260-6. doi:10.1210/jc.2007-1550

38. Cindrova-Davies T, Yung HW, Johns J, Spasic-Boskovic O, Korolchuk S, Jauniaux E, et al. Oxidative stress, gene expression, and protein changes induced in the human placenta during labor. Am J Pathol (2007) 171:1168-79. doi:10.2353/ajpath.2007.070528

39. Keck PJ, Hauser SD, Krivi G, Sanzo K, Warren T, Feder J, et al. Vascular permeability factor, an endothelial cell mitogen related to PDGF. Science (1989) 246:1309-12. doi:10.1126/science.2479987

40. Leung DW, Cachianes G, Kuang WJ, Goeddel DV, Ferrara N. Vascular endothelial growth factor is a secreted angiogenic mitogen. Science (1989) 246:1306-9. doi:10.1126/science.2479986

41. Maynard SE, Min JY, Merchan J, Lim KH, Li J, Mondal S, et al. Excess placental soluble fms-like tyrosine kinase 1 (sFlt1) may contribute to endothelial dysfunction, hypertension, and proteinuria in preeclampsia. J Clin Invest (2003) 111:649-58. doi:10.1172/JCI17189
42. Cindrova-Davies T, Sanders DA, Burton GJ, Charnock-Jones DS. Soluble FLT1 sensitizes endothelial cells to inflammatory cytokines by antagonizing VEGF receptor-mediated signalling. Cardiovasc Res (2011) 89:671-9. doi:10.1093/ $\mathrm{cvr} / \mathrm{cvq} 346$

43. Semenza GL. Regulation of mammalian $\mathrm{O} 2$ homeostasis by hypoxia-inducible factor 1. Annu Rev Cell Dev Biol (1999) 15:551-78. doi:10.1146/annurev. cellbio.15.1.551

44. Jain S, Maltepe E, Lu MM, Simon C, Bradfield CA. Expression of ARNT, ARNT2, HIF1 alpha, HIF2 alpha and Ah receptor mRNAs in the developing mouse. Mech Dev (1998) 73:117-23. doi:10.1016/S0925-4773(98) 00038-0

45. Covello KL, Kehler J, Yu H, Gordan JD, Arsham AM, Hu C, et al. HIF-2alpha regulates Oct-4: effects of hypoxia on stem cell function, embryonic development, and tumor growth. Genes Dev (2006) 20:557-70. doi:10.1101/gad.1399906

46. Nevo O, Soleymanlou N, Wu Y, Xu J, Kingdom J, Many A, et al. Increased expression of sFlt-1 in in vivo and in vitro models of human placental hypoxia is mediated by HIF-1. Am J Physiol Regul Integr Comp Physiol (2006) 291:R1085-93. doi:10.1152/ajpregu.00794.2005

47. Gould PS, Gu M, Liao J, Ahmad S, Cudmore MJ, Ahmed A, et al. Upregulation of urotensin II receptor in preeclampsia causes in vitro placental release of soluble vascular endothelial growth factor receptor 1 in hypoxia. Hypertension (2010) 56(1):172-8. doi:10.1161/HYPERTENSIONAHA.110. 152074

48. Koh MY, Powis G. Passing the baton: the HIF switch. Trends Biochem Sci (2012) 37:364e372. doi:10.1016/j.tibs.2012.06.004

49. Cipolla MJ, Bishop N, Vinke RS, Godfrey JA. PPAR\{gamma\} activation prevents hypertensive remodeling of cerebral arteries and improves vascular function in female rats. Stroke (2010) 41:1266-70. doi:10.1161/ STROKEAHA.109.576942

50. Marx N, Bourcier T, Sukhova GK, Libby P, Plutzky J. PPAR $\gamma$ activation in human endothelial cells increases plasminogen activator inhibitor type-1 expression: PPAR $\gamma$ as a potential mediator in vascular disease. Arterioscler Thromb Vasc Biol (1999) 19:546-51. doi:10.1161/01.ATV.19.3.546

51. Schaiff WT, Carlson MG, Smith SD, Levy R, Nelson DM, Sadovsky Y. Peroxisome proliferator-activated receptor- $\gamma$ modulates differentiation of human trophoblast in a ligand-specific manner. JClin Endocrinol Metab (2000) 85:3874-81. doi:10.1210/jc.85.10.3874

52. Parast MM, Yu H, Ciric A, Salata MW, Davis V, Milstone DS. PPAR $\gamma$ regulates trophoblast proliferation and promotes labyrinthine trilineage differentiation. PLoS One (2009) 4:e8055. doi:10.1371/journal.pone.0008055

53. McCarthy FP, Drewlo S, English FA, Kingdom J, Johns EJ, Kenny LC, et al. Evidence implicating peroxisome proliferator-activated receptor- $\gamma$ in the pathogenesis of preeclampsia. Hypertension (2011) 58:882-7. doi:10.1161/ HYPERTENSIONAHA.111.179440

54. Harvey AE, Lashinger LM, Hursting SD. The growing challenge of obesity and cancer: an inflammatory subject. Ann N Y Acad Sci (2011) 1229:45-52. doi:10.1111/j.1749-6632.2011.06096.x

55. Subbaramaiah K, Howe LR, Bhardwaj P, Du B, Gravaghi C, Yantiss RK, et al. Obesity is associated with inflammation and elevated aromatase expression in the mouse mammary gland. Cancer Prev Res (2011) 4:329-46. doi:10.1158/1940-6207.CAPR-10-0381

56. OlefskyJM,Glass CK. Macrophages, inflammation, andinsulin resistance.Annu Rev Physiol (2010) 72:219-46. doi:10.1146/annurev-physiol-021909-135846

57. Fruebis J, Tsao TS, Javorschi S, Ebbets-Reed D, Erickson MR, Yen FT, et al. Proteolytic cleavage product of 30-kDa adipocyte complement-related protein increases fatty acid oxidation in muscle and causes weight loss in mice. Proc Natl Acad Sci U S A (2001) 98:2005-10. doi:10.1073/pnas.98.4.2005

58. Ghosh D, Najwa AR, Khan MA, Sengupta J. IGF2, IGF binding protein 1, and matrix metalloproteinases 2 and 9 in implantation-stage endometrium following immunoneutralization of vascular endothelial growth factor in the rhesus monkey. Reproduction (2011) 141:501-9. doi:10.1530/REP10-0475

59. Harris LK, Crocker IP, Baker PN, Aplin JD, Westwood M. IGF2 actions on trophoblast in human placenta are regulated by the insulin like growth factor 2 receptor, which can function as both a signaling and clearance receptor. Biol Reprod (2011) 84:440e446. doi:10.1095/biolreprod.110. 088195 
60. Palm M, Axelsson O, Wernroth L, Basu S. F(2)-isoprostanes, tocopherols and normal pregnancy. Free Radic Res (2009) 43:546-52. doi:10.1080/10715760902902737

61. Longini M, Perrone S, Kenanidis A, Vezzosi P, Marzocchi B, Petraglia F, et al. Isoprostanes in amniotic fluid: a predictive marker for fetal growth restriction in pregnancy. Free Radic Biol Med (2005) 38:1537-41. doi:10.1016/j. freeradbiomed.2005.02.017

62. Ishihara O, Hayashi M, Osawa H, Kobayashi K, Takeda S, Vessby B, et al. Isoprostanes, prostaglandins and tocopherols in pre-eclampsia, normal pregnancy and non-pregnancy. Free Radic Res (2004) 38:91391-8. doi:10.1080/ 10715760412331273421
Conflict of Interest Statement: The author declares that the research was conducted in the absence of any commercial or financial relationships that could be construed as a potential conflict of interest.

Copyright (c) 2016 Kasimanickam. This is an open-access article distributed under the terms of the Creative Commons Attribution License (CC BY). The use, distribution or reproduction in other forums is permitted, provided the original author(s) or licensor are credited and that the original publication in this journal is cited, in accordance with accepted academic practice. No use, distribution or reproduction is permitted which does not comply with these terms. 